\title{
Socially Responsible Human Resource Management and Voluntary Environmental Behavior: The Moderating Effect of Ecocentric Leadership
}

\author{
Md. Al-Amin ${ }^{1}$, Refa Akter², Ayesha Akter ${ }^{3}$, Md. Aftab Uddin ${ }^{4}$ Abdullah Al Mamun ${ }^{5}$
}

Submitted: 16.05.2020. Accepted: 26.03.2021

\section{Abstract}

Purpose: The study examines the influence of socially responsible human resource management (SRHRM) on employees' voluntary environmental behavior (VEB), and it tests the moderating effect of ecocentric leadership (EL).

Design/Method: We adopted deductive reasoning in a positivist paradigm by applying quantitative analytical techniques and structural equation modeling. We selected 187 respondents from clothing industry through a self-administered questionnaire survey in Chattogram, the commercial capital of Bangladesh.

Findings: The outcomes revealed that both SRHRM and EL influence VEB. However, the moderation analysis indicated that EL negatively intervenes in the effect of SRHRM on VEB.

Implications: One of the essential contributions of our study is its development of the knowledge related to valuing, developing, and measuring SRHRM's contribution to improving VEB in a moderated model with the help of EL to ensure long-term sustainability.

Originality: Very little is known about the importance of SRHRM in fostering employees' voluntary environmental behavior, so this study will be one of the first to examine the topic. Moreover, the moderating effect of EL posits that its interaction effect is not substantial in stimulating voluntary environmental behavior if organizations can institutionalize SRHRM.

Keywords: socially responsible human resource management, voluntary environmental behavior, ecocentric leadership.

\section{JEL: C12, C83, D23, J53, Q56}

\footnotetext{
1 Mawlana Bhashani Science and Technology University (MBSTU), Santosh, Tangail-1902, Bangladesh, e-mail: alaminmgtcu@gmail.com; https://orcid.org/0000-0002-6204-2236.

2 Rangamati Science and Technology University, Rangamati-4500, Bangladesh, e-mail: refa.akter.r@gmail.com; https://orcid.org/00000001-5765-7159.

3 University of Chittagong, Chattogram-4331, Bangladesh, e-mail: ayeshakter@cu.ac.bd; https://0rcid.org/0000-0002-7664-924X.

4 Corresponding author; University of Chittagong, Chattogram-4331, Bangladesh, e-mail: mdaftabuddin@cu.ac.bd; https://orcid.org/00000002-9101-7451.

5 University of Chittagong, Chattogram-4331, Bangladesh, e-mail: mamun09@cu.ac.bd; https://orcid.org/0000-0001-9042-8163.
} 


\section{Introduction}

Because of the tremendous pressure from stakeholders, environmental sustainability has become a corporate mantra and is emerging as a vital factor in business organizations' resilience worldwide (Arulrajah, Opatha, and Nawaratne, 2016; Bochniarz, 2018; Biswas, 2021; Bochniarz, 2018). Therefore, recent calls from social and environmental scientists underscore the importance of the responsibility for protecting the Earth from an ecological tsunami (Afsar et al., 2020; Gilal et al., 2020). Apart from organizations' own interest in ensuring ecologically responsible production and processes, it is essential for them to make their employees environmentally aware and conscious (Darnall, Henriques, and Sadorsky, 2008; 2010; Das, Biswas, Jilani, and Uddin, 2019). Consequently, it is essential that human resource management (HRM) in companies are sufficiently responsible for instilling their workforce with clear green goals and policy guidelines (Yusliza et al., 2019). Scholars show that organizations are major polluters that contribute to climate change and ecological imbalance (Das et al., 2019). Therefore, simply being environmentally friendly in production and process systems will not be enough (Robertson and Barling, 2013) if HRM fails to integrate its work processes and methods to reduce the redundancy of energy and carbon emissions (Paillé et al., 2016).

Moreover, environmental behavior, mainly voluntary environmental behavior (VEB), is carefully paired with green HRM, facilitated by socially responsible human resource management (SRHRM), which stems from corporate social responsibility (Koładkiewicz, 2009; Cruz et al., 2014; Harangozó, Széchy, and Zilahy, 2015), HRM ethics, and various employee-oriented human resource practices (Shen and Zhang, 2019). Environmentally responsible talent is scarce, so SRHRM now emphasizes the recruitment of eco-friendly talent to help respond to the pressing needs of organizational sustainability. Talent management with environmental consideration is vital in the response to ecological demands (Vokić, 2015). Leadership ensures the higher external motivation of employees (Baczynska and Korzynski, 2017; Buzady, 2017). When leaders demonstrate ecocentric leadership (EL), subordinates voluntarily behave in an eco-friendly way; for example, by saving electricity, reducing wastepaper, saving water, biochemical, and reducing degradation of the soil. Leaders' green behaviors support green innovation, rewards, and recognition, while the achievement of subordinates' goals influences the promotion of eco-initiatives (Pham and Kim, 2019; Tuan, 2019; Afsar et al., 2020).

The consequential influences of SRHRM and EL on employees' VEB can arguably be predicted from domains of social exchange theory and environmental leadership theory. Social exchange theory (SET) proposes a mutual understanding of the interac- 
tion in transactional relationships (Blau, 1964). Among the many other theories explaining the relationship between SRHRM and environmental behavior, SET posits that exchange in a social milieu entails a series of complementary yet beneficial actions and reactions by the concerned parties (Fan, Mahmood, and Uddin, 2019). Blau (1964) postulates that successful exchange between parties is contingent on how each reciprocates in the social exchange mechanism. In short, the action of one party depends on the extent of the rewarding reaction of another party in a formal transactional interaction (Blau, 1964; Homans, 1958). SET significantly explains the association between SRHRM and EL action and the reaction of employees' VEB. Following the tenets and assumptions of SET, this study advocates that the level of employees' engagement in VEB will largely depend on adequate support and the active roles of SRHRM and EL in relation to employees and the environment.

Accordingly, with the help of effective leadership, EL and SRHRM can lead to notable results, as EL is linked with subordinates' eco-friendly concerns for the environment, which impact their pro-environmental behaviors (Robertson and Barling, 2013; Uddin et al., 2021). We observed exponential growth in corporate social responsibility studies for influencing employees' performance (Edwards and Kudret, 2017; Sun and Yu, 2015). Surprisingly, there is a lack of studies on the impact of SRHRM on employees in VEB. Numerous studies investigated the influence of regulatory focus on environmental behavior by holistically scrutinizing required and voluntary environmental behavior (Norton et al., 2015; Ciocirlan, 2017; Yuriev et al., 2018). However, this study endeavors to examine the potential influence of SRHRM and EL on VEB because, as indicated above, less attention has been paid to valuing, developing, and measuring the contribution of SRHRM to stimulating employees' VEB (Uddin et al., 2020). Therefore, this research gap has motivated us to conduct this study in order to fill the gap from the perspective of non-Western countries.

\section{Literature Review}

\section{Socially Responsible Human Resource Management}

Socially Responsible Human Resource Management and HRM are similar notions. When an organization retools and rethinks its HRM tasks to cater to the pressing needs of the society in which it works, HRM becomes SRHRM (Shen and Zhang, 2019). The latter originates from the work of Shen and Zhu (2011) and is a distinct discipline that includes HRM legal compliance, employees' concerns, and its general CSR facilitation (Shen and Zhang, 2019). The need to save the planet from further decay, save energy, and reduce carbon has become a megatrend in the corporate world (Longoni, 
Luzzini, and Guerci, 2018). An obligation to prevent the further degradation of the planet is demanded because of employees' limited knowledge of the environment, which in consequence drives top management needs to develop sustainable organizational practices in line with SRHRM, with particular regard to the corporate triple bottom line: profit, planet, people.

SRHRM conveys eco-friendly initiatives such as using cleaner and greener technologies, recycling products, producing water energy and drinkable water, limiting the use of fossil fuels, and making the workplace paperless or less paper-reliant. SRHRM can be translated into action by establishing obligatory green laws for employing the most ecocentric candidates after evaluating their resumes, which should be linked with pro-social initiatives and green passion and values (Newman et al., 2016). Consequently, SRHRM will develop and maintain a sense of alignment among employees toward the organization and its ecological environment when they observe that HRM is socially responsible (Shen and Zhu, 2011).

\section{Voluntary Environmental Behavior}

Environmental behavior refers to employees in the working environment who perform their duties concerning the natural environment (Eilam and Trop, 2012; Araújo, 2014; Kil, Holland, and Stein, 2014). Cantor, Morrow, and Blackhurst (2015) categorize environmental behavior into two broad groups: in-role (customary or task-role) and extra-role (voluntary or pro-environmental). Studies posit that employees' discretionary behavior or VEB tremendously impacts natural environment protection, much more than laws preventing environmental degradation (Das et al., 2019; Fu et al., 2020; Liu, Teng, and Han, 2020). It is undoubtedly favorable to the organization and the planet as a whole if employees display any sort of eco-friendly behavior (Safari et al., 2018). Responses that exceed organizational expectations and formal regulatory requirements are treated as VEB (Kim et al., 2017), which may include using recycled paper and reusable products (Paillé et al., 2016), powering down during non-working periods and off-peak hours, effectively using office supplies, conserving energy, and utilizing cleaner and greener technology (Kim et al., 2017).

\section{Ecocentric Leadership}

The Silicon Valley Leadership Group states that today's corporate leaders must adopt green objectives to compete successfully, satisfy green consumers, secure top market positions, and become industry leaders. It defines EL as the ability to influence followers to behave in an eco-friendly way and look forward to achieving the organization's 
green goals. An organization following a sustainability program demonstrates a green mindset that will encourage employees to be involved in environmentally friendly activities and eco-innovation (Archibald et al., 2009; Kim et al., 2017; Bochniarz, 2018). Leaders are the role models in the organization, and their VEB indicates their concerns for environmental sustainability, which encourages employees to consider the environmental impact when undertaking any activity (Kim et al., 2017). Leaders' eco-friendly behavior directly impacts subordinates' environmental behavior (Norton et al., 2015).

\section{Hypothesis Development}

\section{Socially Responsible Human Resource Management and Voluntary Environmental Behavior}

The notion of SRHRM is a relatively new field of study (Shen and Zhu, 2011; Newman et al., 2016; Shen and Benson, 2016; Barrena-Martinez et al., 2018). Studies demonstrate that SRHRM significantly impacts employees' commitment (Shen and Zhu, 2011), citizenship behavior (Newman et al., 2016), work behavior (Shen and Benson, 2016), competitive performance (Lechuga Sancho et al., 2018), organizational competitiveness (Ferdausy et al., 2018) and employees' CSR initiatives (Shen and Zhang, 2019). Ferdausy et al. (2018) show that the presence of SRHRM with regard to the environment, CSR, and employee facilitation increases the sense of moral obligation among employees to display their skills in protecting the organization and its surrounding natural environment.

SRHRM encourages and rewards employees for performing eco-friendly behavior with extrinsic and intrinsic benefits, which enhance their further engagement in VEB (Srivastava and Shree, 2019). The influence of SRHRM on VEB is similar to the core understanding of SET because it encourages employees to reciprocate when they understand that their SRHRM is designing a workplace with particular reference to social contributions, eco-friendly policies, and practices to ensure employees' wellbeing (Berrone et al., 2013; García-Quevedo, Kesidou, and Martínez-Ros, 2020). A firm's obligation leads employees toward VEB for the betterment of the organization in the long run (Homans, 1958; Blau, 1964; Lee, Kim, and Kim, 2018).

Organizations fostering an SRHRM culture adopt ethical codes of conduct, are identified as eco-friendly, and vitalize employees' VEB (Tian and Robertson, 2019). The findings of Tian and Robertson (2019) show that self-belief is defined and shaped by one's concern toward essential others, which drives people to comply with expected behaviors. Consequently, when employees have confidence in their organizations and 
that SRHRM encourages and reinforces their VEB, their intention to act accordingly increases. Based on this theoretical and empirical underpinning, we hypothesize that:

H1: Socially Responsible Human Resource Management has a positive influence on employees' VEB.

\section{Ecocentric Leadership and Voluntary Environmental Behavior}

Ecocentric Leadership refers to leaders' behaviors that motivate followers to achieve environmental goals and inspire them to perform beyond expected ecological performance levels (Davis and Macauley, 2011). An environmental leadership style positively impacts employees' VEB (Robertson and Barling, 2013). Green leaders motivate employees to display VEB by setting environmental epistemology at the individual and group levels (Yi, Li, and Jai, 2018). Moreover, they set environmental group goals with collective beliefs, values, and norms, which motivate employees' VEB. By promoting a green vision, ecocentric leaders encourage their followers to engage in voluntary green activities based on their opinions, creative thinking, and innovation in order to achieve a green vision beyond expectations (Robertson and Carleton, 2018; Tuan, 2019). Ecocentric Leadership influences employees' mindfulness and creates the awareness of environmental information and knowledge to display VEB (Robertson and Barling, 2013). Moreover, Afsar et al. (2020) demonstrate that the leader who crafts a green shared vision and green initiatives can motivate employees' eco-specific behavior. Therefore, we hypothesize that:

H2: Ecocentric leadership has a positive influence on employees' VEB.

\section{The Moderating Effect of Ecocentric Leadership}

The literature provides sufficient evidence of the compelling influence of SRHRM practices in stimulating employees' eco-friendly activities (Shen, Dumont, and Deng, 2018). Organizations that undertake SRHRM practices ensure the recruitment of employees with environmental values and beliefs. Moreover, they arrange training programs that help to foster environmental revolutions in the organization (Dumont, Shen, and Deng, 2017). In our research, we assert that supervisors' EL will moderate the direct influence of SRHRM on VEB. An SRHRM policy will seek to recruit green employees able to continuously implement the green vision and achieve green environmental goals (Moore et al., 2019). Encouraging green talent influences employees' attitudes, norms, and behaviors toward voluntary green environmental activities (Khan et al., 2019). Studies have shown that EL - particularly its intervening role - is a prerequisite for corporate green- 
ing by implementing a deep-seated passion for shaping greening initiatives and putting green practices into action by engaging subordinates (Graves, Sarkis, and Zhu, 2013; Boiral, Baron, and Gunnlaugson, 2014; Kim et al., 2019; Khuwaja et al., 2020). When employees have eco-friendly leaders and direct support from SRHRM, they will be more enthusiastic and passionate toward VEB following SET understanding. Despite the fact that Eisenbeiß and Boerner (2013) and Michaelis, Stegmaier, and Sonntag (2010) posit that excessive compliance with supervisors creates dependency, there is a growing body of literature in support of the influence on subordinates' behavior. Accordingly, the positive effect of SRHRM on VEB will be strengthened when the level of EL is high, and conversely, it will be weakened when the EL level is low. Therefore, we hypothesize that:

H3: Ecocentric Leadership moderates the influence of SRHRM on VEB because high-level EL strengthens its positive impact, and vice versa.

Figure 1 shows the research framework as a multilevel model including the individual-level (VEB) and the organizational-level variables (SRHRM and EL). Drawing on the understanding of SET and the related literature on SRHRM and EL, we developed the following Figure 1.

\section{Figure 1. Conceptual research framework}

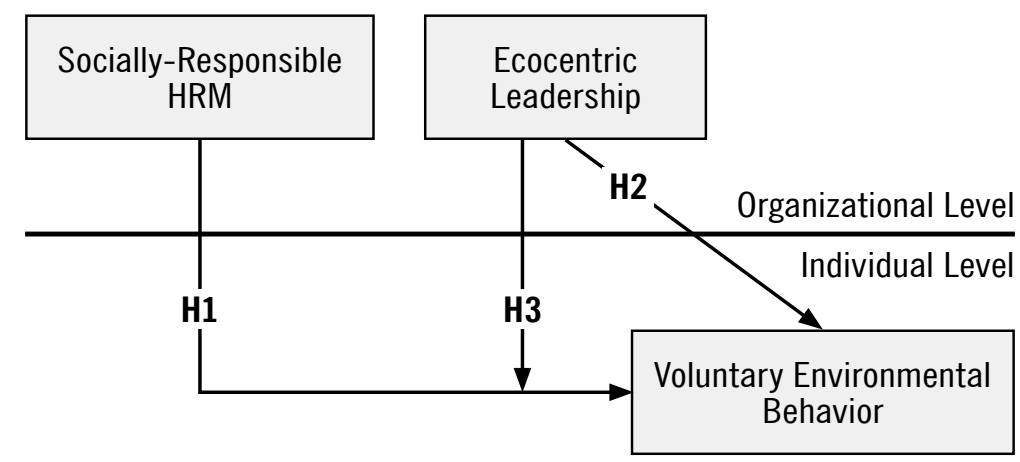

Source: own elaboration.

\section{Research Method}

\section{Research Design and Data Collection Procedure}

We collected respondents' data from the Ready-Made Garment (RMG) industry in Chattogram, a commercial city thriving thanks to the influence of the sector on Bangladesh's foreign exchange inflows. The study followed a self-administered survey 
method. Chattogram was purposively chosen to generate the data as it is the commercial capital and financial hub of Bangladesh. The convenience sampling method was considered appropriate because the nature of the respondents was homogenous due to the small diversity in Bangladesh other than such as age, gender, or education (Fan et al., 2019).

Two separate sets of questionnaires were distributed to respondents to prevent response bias and social desirability bias (Fan et al., 2019; Mahmood, Uddin, and Luo, 2019; Uddin, Priyankara, and Mahmood, 2020). In line with Podsakoff, MacKenzie, and Podsakoff (2012), we followed the procedure of Azim et al. (2019) to generate other responses. In this way, the study collected pairs of responses from leaders and subordinates. The leaders reported on subordinates' VEB, while the subordinates reported on their leaders' EL style and the organization's SRHRM.

The interviewers visited relevant departments to deliver the questionnaire and briefed the participants on how to respond to the two questionnaires. Each organization was considered a unit. One manager or head of the department and one subordinate were chosen to respond to each pair of questionnaires. To ensure the accuracy of their responses, we guaranteed confidentiality. The respondents were given fifteen days to complete and submit the questionnaire. We distributed 250 questionnaires and received 187 completed replies, representing a response rate of $74.80 \%$. The response rate and size of the sample were adequate for performing multivariate data analysis (Fan et al., 2019; Uddin et al., 2020; Uddin et al., 2020).

\section{Participant Information}

Descriptive results revealed that females outnumbered their male counterparts with participation at 95\%. The average age and tenure of the respondents were 33.4 and 7.5 years, respectively. Among participants, 50.8\% had received a postgraduate degree while the remainder (49.2\%) had completed undergraduate degrees at distinct educational institutions. Most respondents came from small and medium-sized organizations. Among the 187 respondents, 161 (86.1\%) worked at small and medium-sized enterprises, and the remaining 26 respondents (13.9\%) were employed by large organizations.

\section{Response Bias}

We guaranteed the respondents privacy and confidentiality in order to ensure accurate responses. First, we assured them that all the data would be kept private and that we were reporting on corporate phenomena in the industry as a whole rather than on 
specific organizations (Mahmood et al., 2019; Uddin, Mahmood, and Fan, 2019). Second, we ran Harman's single factor test to identify any variable that explained more than $50 \%$ of the variance. Interestingly, the predicted outcome was $35.75 \%$, less than $50 \%$ of the total variance $(75.23 \%)$. We assessed the correlation test again to examine all the interrelationships outpacing 0.9. The results showed a maximum correlation between any two tests of 0.475 . Therefore, there was no issue with response bias (Mahmood et al., 2020).

\section{Measurement Tools}

We identified multi-item measurement tools applied in similar settings in previous studies. The measurements we used are listed in Appendix 1. Accordingly, SRHRM was measured according to the method used by Shen and Zhu (2011), who measure three dimensions: employee orientation, legal compliance, and general facilitation. Ecocentric Leadership was measured following Ramus (2001), while VEB was measured following Robertson and Barling (2013). Next, we followed Brislin's (1970) back-translation procedure to translate the original measurement tools into Bangla in order to generate accurate replies from the native Bengali. We employed a panel of academic and professional experts to apply the back-translation procedure to the context of the survey measures. The Bangla version (native language) was then pretested on 20 executives, comprising supervisors and subordinates working in different organizations. Finally, we refined the final questionnaire by considering the feedback from the pilot test (Azim et al., 2019). The responses were measured on a five-point Likert scale, ranging from 1 (strongly agree) to 5 (strongly disagree).

\section{Analysis and Model Evaluation}

The study adopted a second-generation structural equation modeling (SEM) that comprehensively assessed the measurement and structural models (Das et al., 2019; Uddin et al., 2020). The primary rationale for using SEM over other regression techniques is its inherent robustness and exhaustiveness in estimating and reporting results in an advanced manner. Notably, it reveals the strength of the relationships between independent and dependent variables and displays the overall predictability of the model in a holistic way. Via Amos 20, SEM estimates both models together. The measurement model reports reliabilities and validities, together with confirmatory factor analysis (CFA), while the structural model includes t-statistics, beta-coefficients, $\mathrm{R}^{2}$, and the goodness of fit index (GFI). 


\section{Measurement Model}

We tested the measurement model using multiple criteria. Primarily, CFA was used to estimate the fit index. Apart from this estimation, we estimated other fitness measures to attest to the suitability measurement model. The calculated results displayed in Table 1 show a good fit $[\chi 2 / \mathrm{df}=1.323, \mathrm{RMR}=0.035$, $\mathrm{RMSEA}=0.042, \mathrm{TLI}=0.966$, and CFI $=0.97$ ] (Hooper, Coughlan, and Mullen, 2008; Hair Jr et al., 2014; Souto, 2015). We also evaluated the reliabilities and validities. Concerning the composite reliability, we observed that the minimum score of measures was 0.869 (GF), signifying that the threshold limit was realized (Hair Jr et al., 2014; Zikmund et al., 2010). The average variance extracted (AVE) was also checked, with the estimates showing that a minimum AVE of 0.50 was achieved for all constructs. Since the minimum AVE (AVE of $\mathrm{EL}=0.651$ ) was greater than 0.50 for any scale, convergent validity was guaranteed (Hair Jr et al., 2014). Discriminant validity is authenticated if the construct's AVE's square root is higher than its association with other constructs (Hair Jr et al., 2014). Therefore, both the convergent validity and discriminant validity scores (Table 2) show that there were no issues with the measurement model.

Table 1. Measurement model fit indices

\begin{tabular}{|l|c|c|c|c|c|}
\hline \multicolumn{1}{|c|}{ Index } & $(\boldsymbol{\chi} \mathbf{2} / \mathbf{d f})$ & RMR & RMSEA & TLI & CFI \\
\hline Threshold Value & $<5.0$ & $<0.08$ & $<0.08$ & $>0.90$ & $>0.90$ \\
\hline Measurement Model & 1.323 & 0.035 & 0.042 & 0.966 & 0.970 \\
\hline
\end{tabular}

Note: RMR and RMSEA: lower the better. TLI and CFI can range 0-1; RMR - Root Mean Square Residual; RMSEA - Root Mean Square Error of Approximation; TLI - Tucker-Lews index; CFI - Confirmatory Fit Index.

Source: own elaboration.

Table 2. Convergent and discriminant validities

\begin{tabular}{|c|c|c|c|c|c|c|c|c|c|c|}
\hline Variables & 1 & 2 & 3 & 4 & 5 & 6 & 7 & 8 & 9 & 10 \\
\hline \multicolumn{11}{|l|}{$\begin{array}{l}\text { Control } \\
\text { variables }\end{array}$} \\
\hline 1. Age & 1 & & & & & & & & & \\
\hline 2. Tenure & $.949 * *$ & 1 & & & & & & & & \\
\hline 3. Education & .061 & .038 & 1 & & & & & & & \\
\hline 4. Size & .094 & $.166^{*}$ & .052 & 1 & & & & & & \\
\hline 5. Gender & -.129 & -.138 & -.014 & -.099 & 1 & & & & & \\
\hline
\end{tabular}




\begin{tabular}{|c|c|c|c|c|c|c|c|c|c|c|}
\hline $\begin{array}{l}\text { Latent } \\
\text { variabl }\end{array}$ & & & & & & & & & & \\
\hline 6. EO & $.292 * *$ & $.278 * *$ & .032 & $.211 * *$ & -.014 & 0.820 & & & & \\
\hline 7. VEB & $.261^{\star \star}$ & $.248 * *$ & $.183^{\star}$ & .135 & -.010 & $0.367 * *$ & 0.830 & & & \\
\hline 8. EL & $.252 * *$ & $.248 * *$ & .031 & $.155^{*}$ & $-.148 *$ & $0.423 * *$ & $0.417 * *$ & 0.807 & & \\
\hline 9. LC & $.259 * *$ & $.197 * *$ & -.004 & .086 & -.095 & $0.407 * *$ & $0.355^{\star *}$ & $0.475^{* *}$ & 0.825 & \\
\hline 10. GF & $.225^{\star *}$ & $.193 * *$ & $.194 * *$ & .097 & -.032 & $0.375^{* *}$ & $0.290 * *$ & $0.431^{* *}$ & $0.387 * *$ & 0.831 \\
\hline CR & - & - & - & - & - & 0.891 & 0.939 & 0.918 & 0.914 & 0.869 \\
\hline AVE & - & - & - & - & - & 0.672 & 0.689 & 0.651 & 0.681 & 0.69 \\
\hline Mean & 33.40 & 7.49 & - & - & - & 4.027 & 3.976 & 4.078 & 4.129 & 3.766 \\
\hline SD & 7.115 & 6.159 & - & - & - & 0.718 & 0.742 & 0.708 & 0.719 & 0.784 \\
\hline
\end{tabular}

** Correlation is significant at the 0.01 level (2-tailed), * Correlation is significant at the 0.05 level (2-tailed); LV - latent variable; CR - composite reliability; EO - employee orientation; VEB - voluntary environmental behavior; EL - ecocentric leadership; LC - legal compliance; GF - general facilitation; CR - Composite reliability; AVE - Average variance extracted; SD - Standard deviation.

Source: own elaboration.

\section{Structural Model}

We also tested the structural model with the fit index and the results displayed an excellent fit $\left[\chi^{2}(443)=528.00, p=0.000 ; \mathrm{CMIN} / \mathrm{DF}=1.298, \mathrm{RMR}=0.058, \mathrm{CFI}=0.970\right.$, $\mathrm{TLI}=0.967$, RMSEA $=0.040$, consistent with the threshold limit (Hair Jr, Black, et al., 2014; Hooper et al., 2008).

\section{Hypothesis Testing}

\section{Direct Effects}

We first tested the direct effects of SRHRM and EL on VEB (see Table 3). In H1, we proposed that SRHRM has a significant influence on VEB. The estimates were in line with this, with a significant influence $(\beta=0.374, p=0.000)$. Consequently, H1 is supported. In H2, we posited that EL influences VEB. The results presented in Table 3 also support this prediction, indicating that EL significantly predicts $(\beta=0.255$, $\mathrm{p}=0.007$ ) employees' VEB. Accordingly, H2 is also supported. 
Table 3. Estimates on direct effects

\begin{tabular}{|c|c|c|c|c|c|c|c|}
\hline Hypothesis & \multicolumn{3}{|c|}{ Path-Relations } & Estimate & S.E. & C.R. & $\mathbf{P}$ \\
\hline $\mathrm{H} 1$ & VEB & $<-$ & SRHRM & 0.374 & 0.263 & 3.514 & 0.000 \\
\hline $\mathrm{H} 2$ & VEB & $<-$ & EL & 0.255 & 0.094 & 2.710 & 0.007 \\
\hline
\end{tabular}

VEB - voluntary environmental behavior; EL - ecocentric leadership; SRHRM - socially responsible human resource management.

Source: own elaboration.

\section{Moderating Effect}

H3 proposes that EL moderates the influence of SRHRM on VEB. The PROCESS macro estimates shown in Table 4 demonstrate that EL negatively moderates $\left(\beta_{\mathrm{SRHRM}^{*} \mathrm{EL}}=-2.388\right.$, $p=0.000$ ) the influence of SRHRM on VEB, which indicates that high EL weakens the influence of SRHRM on VEB, and while low EL strengthens it. More specifically, the findings show that a high level of EL significantly reduces the positive effect of SRHRM on VEB, while a low level substantially increases it. The following figure 2 shows that EL dampens the positive relationship between SRHRM and VEB; when EL is high; the ties between VEB and SRHRM are negative, and vice versa. Finally, hypothesis 3 is not supported, as we hypothesized the positive moderating influence on the relationship mentioned above.

Table 4. Moderating effect of ecocentric leadership

\begin{tabular}{|l|c|c|}
\hline \multirow{2}{*}{ Variables } & \multicolumn{2}{c|}{ Voluntary environmental behavior } \\
\hline SRHRM & Model $\mathbf{1}$ & Model 2 \\
\hline EL & $0.308^{*}$ & - \\
\hline SRHRM & $0.236^{* *}$ & - \\
\hline EL & - & $0.966^{* *}$ \\
\hline SRHRM*EL & - & $1.024^{* *}$ \\
\hline$R^{2}$ & - & $-2.388^{* *}$ \\
\hline$\Delta R^{2}$ & 0.229 & 0.253 \\
\hline
\end{tabular}

** $p<0.000,{ }^{*} p<0.005$; VEB - voluntary environmental behavior; EL - ecocentric leadership; SRHRM - socially responsible human resource management.

Source: own elaboration. 
Figure 2. Moderating effect of ecocentric leadership

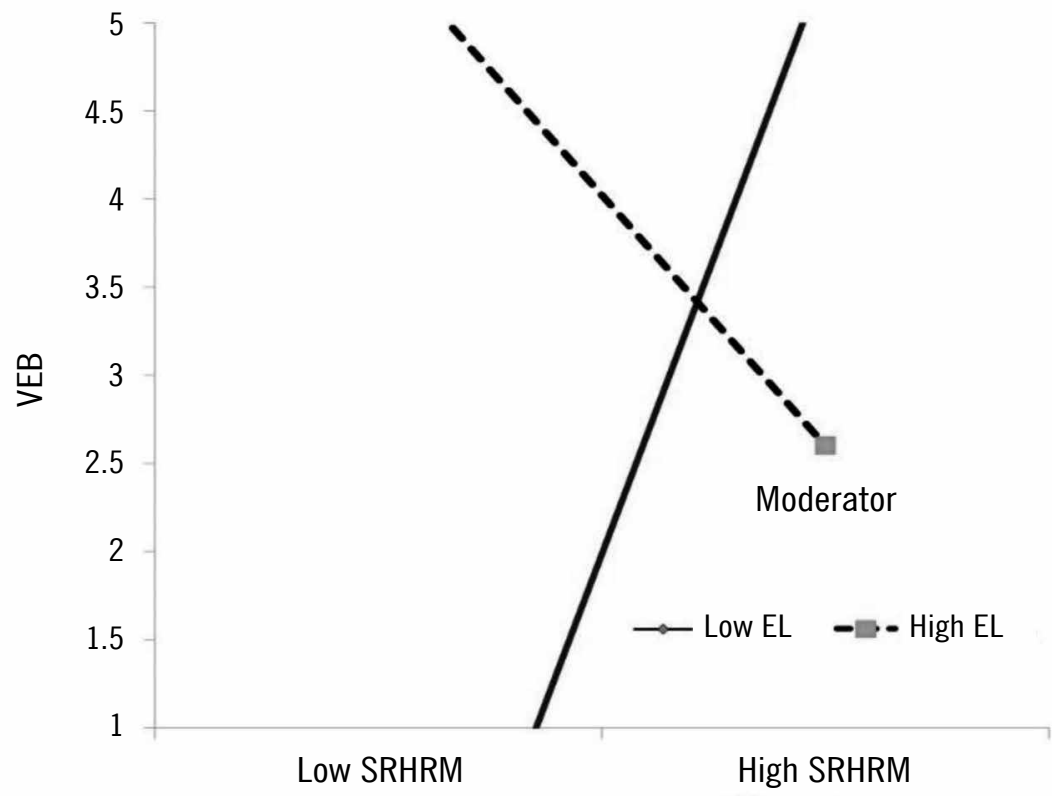

EL - Eco-centric leadership, SRHRM - Socially responsible human resource management, VEB - Voluntary environmental behavior.

Source: own elaboration.

\section{Discussion}

This study was conducted from both empirical and theoretical perspectives to determine the strength of the influence that SRHRM has on VEB. The study also tested the moderating effect of EL, bearing in mind that any behavior is reasoned from multilevel perspectives (Mahmood et al., 2019). The study outcomes based on the empirical evidence demonstrate that employees spontaneously become involved in VEB if they receive holistic support (Das et al., 2019). Therefore, in line with SET, we may posit that these behaviors will be repeated more often by recipients when their efforts are reinforced by SRHRM (Homans, 1958; Blau, 1964).

Our first hypothesis proposed that VEB is influenced by SRHRM, based on empirical and theoretical relevance. The study has demonstrated a very high level of impact of SRHRM on VEB $(\beta=0.374, p=0.000)$. Therefore, we may conclude that the preceding previous outcomes also support the results of this study regarding SRHRM's important influence on VEB because many previous findings showed that eco-friendly 
policies, codes of conduct, and cultural development by organizations encourage employees to think pro-environmentally and participate in VEB (Burke, Borucki, and Kaufman, 2002; Schneider, Ehrhart, and Macey, 2013). Moreover, based on organizations' performance management, the participation of their members in VEB varies significantly. Employees become more socially responsible toward organizations if SRHRM deals with them with due process by offering ecocentric HRM activities (Shen and Zhu, 2011).

We hypothesized in $\mathrm{H} 2$ that EL predicts voluntary environmental behavior. Previous studies find a marked influence of EL on VEB (Robertson and Barling, 2013; Kim et al., 2017; Khan et al., 2019), which agrees with the findings of our study. Therefore, our findings are consistent with those of previous studies that the environmental behavior of leaders encourages subordinates to engage in more discretionary environmental behavior (Jang, Zheng, and Bosselman, 2017; Robertson and Carleton, 2018; Tuan, 2019). This is because leaders' green goals and visions encourage their followers to display environmental behavior.

Hypothesis 3 highlighted the moderating effect of EL on the influence of SRHRM on VEB. Surprisingly, our study found a negative moderating impact of EL on the observed influence of SRHRM on VEB. The results confirm that high EL weakens the positive effect of SRHRM on VEB, while conversely, the low level strengthens the impact. Our results are in line with the findings of previous studies (Eisenbeiß and Boerner, 2013), meaning that excessive demonstration of EL and exertion of the influence of SRHRM on VEB turn the positive effect of SRHRM on VEB negative. The results demonstrate that the high level of EL and manifestation of SRHRM results in low involvement in VEB, and vice versa. Therefore, this signifies the reverse interaction effects on the VEB of employees. One of the dominant reasons for this inverse relationship might be the role conflict between leadership and human resource managers. In Figure 2, we see that both EL and SRHRM are positive predictors of VEB. Notably, SRHRM is more potent than EL. This finding agrees with the study of Michaelis et al. (2010), who also found that overreliance on external influences on VEB should be kept to a minimum.

\section{Conclusion}

\section{Contributions}

This study makes significant contributions to the field of management science. There are many studies of HRM and organizational behavior, but few discuss SRHRM. Noteworthy, no previous studies show how SHRM and EL influence employees' VEB, 
a process that could change HR professionals' approach by moving their mindset away from traditional HRM. This study's empirical findings show that many organizations are morally accepted by their workforce because of their societal concern and formulation of HR policies and practices to stimulate them toward eco-friendly behavior. This is evidenced by managers' urgency to develop eco-friendly management policies that are employee-oriented and concerned with the community as eco-concerned employees appreciate these greatly.

The results demonstrate the ethical concerns that organizations should have toward society by exhibiting green awareness. Organizations' positive attitudes and intentions toward environmental initiatives will generate more VEB and thus accelerate their success. Another significant contribution of the study is its discussion of the use of EL in strengthening the influence of SRHRM on VEB. Unexpectedly, the study revealed that EL negatively moderates the effect of SRHRM on VEB, which implies that the application of SRHRM suffices to nurture VEB in the organizational context. Moreover, adopting green concepts in policies and recruiting green employees ensures their green motivation, which may suggest there is no need for additional guidance on green initiatives on the part of leaders. This finding is a unique contribution of this study, which contradicts those of previous studies. However, it provides an essential lesson that an excessive demonstration of regulatory focus can negate previous positive influences, as becomes clear in Table 4. Moreover, our finding reveals that the organization's green policy, eco-friendly training programs, and rewards and recognition for green performance are sufficient to influence employees to display voluntary environmental behavior without a major influence from EL.

\section{Practical Implications}

The article focuses on the HRM's social responsiveness, which makes the working environment friendly to the workforce and reshapes managing people in a socio-ecological manner. We demonstrated that practicing SRHRM encourages employees to display eco-centric behavior voluntarily if the organization assures a conducive environment. Employees' VEB helps managers attain organizational efficiency by reducing unwanted expenditure on paper use and energy consumption. The SRHRM strategy provides organizations with a direction for cultivating green practices and an atmosphere to instill and nurture employees' VEB, which provides vital resources and a foundation for their sustainable development. Therefore, firms should involve their workforce in VEB without compelling them to do so in order for them to play an environmental role. Moreover, the increasing importance of environmental activities requires organizations to incorporate both strategic needs and the claims of internal 
and external stakeholders. In this regard, SRHRM provides critical insight into satisfying strategic employees' needs, thus motivating competent eco-concerned employees and resulting in better organizational performance. Finally, organizations must be cautious when choosing an appropriate leadership style in teams. Table 4 shows that both SRHRM and EL positively influence VEB, but the interaction effect of EL on the influence of SRHRM on VEB is negative. This confirms that excessive pressures from multiple perspectives on engaging employees in VEB are fruitless. A minimal influence of ecocentric leadership can minimize the conflicts between leaders and subordinates in terms of their green perceptions. Therefore, this interaction can be an additional burden on employees in performing and implementing organizations' green visions. Organizations must balance SRHRM and EL to extract the best environmental behavior from their employees because we observed a negative interaction effect of EL.

\section{Limitations and Future Directions}

Although this study has made many useful contributions to advancing the theory of and highlighting managerial practices, it has drawbacks that prevent the broader generalizability of its findings. First, regarding the empirical results, the sample size is relatively small, which limits the causality of the findings. Therefore, future researchers should find more respondents to make their outcomes more generalizable. Second, we used cross-sectional data (a one-time survey) to collect the sample, which had an impact on the generalizability of the findings. Therefore, we suggest that future researchers collect the sample from a multi-wave study or employ longitudinal data to make the results more acceptable. Finally, this research has revealed the negative moderating effect of EL on the influence of SRHRM on VEB. Future researchers could explore the reason behind this surprising finding by employing both a mixed-methods survey and interviews. Furthermore, the application of the same model would ensure the validation and triangulation of our findings. Moreover, the nature of this study is a typical deductive reasoning approach: a mono method. In the deductive reasoning approach, researchers can predict the scenario by considering the perspectives of others. On the other hand, different types of reasoning (inductive) recognize the researcher as part of the process, while denying others' perspectives. Therefore, we urge future researchers to use a mixed-method approach to ensure the causality of our findings.

\section{$\underline{\text { References }}$}

Afsar, B., Maqsoom, A., Shahjehan, A., Afridi, S.A., Nawaz, A., and Fazliani, H. (2020). Responsible leadership and employee's proenvironmental behavior: The role of organizational commitment, green shared vision, and internal environmental locus of control. Corporate Social Responsibility and Environmental Management, 27(1), 297-312. http:/dx.doi.org/10.1002/csr.1806. 
Araújo, F.F. (2014). Do I Look Good In Green? A Conceptual Framework Integrating Employee Green Behavior, Impression Management, and Social Norms. Amazônia, Organizações e Sustentabilidade, 3(2), 7-23. http://dx.doi.org/10.17800/2238-8893/aos.v3n2p7-23.

Archibald, S.O., Bochniarz, Z., Gemma, M., and Srebotnjak, T. (2009). Transition and sustainability: empirical analysis of environmental Kuznets curve for water pollution in 25 countries in Central and Eastern Europe and the Commonwealth of Independent States. Environmental Policy and Governance, 19(2), 73-98. http://dx.doi.org/10.1002/eet.499.

Arulrajah, A.A., Opatha, H., and Nawaratne, N. (2016). Employee green performance of job: a systematic attempt towards measurement. Sri Lankan Journal of Human Resource Management, 6(1), 37-62.

Azim, M.T., Fan, L., Uddin, M.A., Jilani, M.M.A.K., and Begum, S. (2019). Linking transformational leadership with employees' engagement in the creative process. Management Research Review, 42(7), 837-858. http://dx.doi.org/10.1108/MRR-08-2018-0286.

Baczynska, A., and Korzynski, P. (2017). Leadership Competences Among Managers. Journal of Management and Business Administration. Central Europe, 25(2), 6-22.

Barrena-Martinez, J., López-Fernández, M., and Romero-Fernandez, P. M. (2018). Drivers and Barriers in Socially Responsible Human Resource Management. Sustainability, 10(5), 1532.

Berrone, P., Fosfuri, A., Gelabert, L., and Gomez-Mejia, L.R. (2013). Necessity as the mother of 'green' inventions: Institutional pressures and environmental innovations. Strategic Management Journal, 34(8), 891-909. http://dx.doi.org/10.1002/smj.2041.

Biswas, S.R. Dey, M., Bhattacharjee, S., and Uddin, M.A. (2021). How does corporate environmental strategy contribute to voluntary environmental behavior? Influence of psychological green climate, firms' size, and employees' age. SAGE Open. https://doi.org/10.1177/21582440211006054.

Blau, P.M. (1964). Justice in social exchange. Sociological Inquiry, 34(2), 193-206. https://doi.org/10.1111/j.1475-682X.1964.tb00583.x.

Bochniarz, Z. (2018). Sustainable Business as the Base for Sustainable Entrepreneurs: Some Theoretical and Practical Reflections. Eruditio, 2(4), 222-249.

Boiral, O., Baron, C., and Gunnlaugson, O. (2014). Environmental Leadership and Consciousness Development: A Case Study Among Canadian SMEs. Journal of Business Ethics, 123(3), 363-383. http://dx.doi.org/10.1007/s10551-013-1845-5.

Brislin, R.W. (1970). Back-translation for cross-cultural research. Journal of Cross-Cultural Psychology, 1(3), 185-216. https://doi.org/10.1177/135910457000100301.

Burke, M.J., Borucki, C.C., and Kaufman, J.D. (2002). Contemporary perspectives on the study of psychological climate: A commentary. European Journal of Work and Organizational Psychology, 11(3), 325-340. http://dx.doi.org/10.1080/13594320244000210.

Buzady, Z. (2017). Flow, leadership and serious games - a pedagogical perspective. World Journal of Science, Technology and Sustainable Development, 14(2/3), 204-217.

http://dx.doi.org/10.1108/WJSTSD-05-2016-0035.

Cantor, D.E., Morrow, P.C., and Blackhurst, J. (2015). An Examination of How Supervisors Influence Their Subordinates to Engage in Environmental Behaviors. Decision Sciences, 46(4), 697-729. http://dx.doi.org/10.1111/deci.12149.

Ciocirlan, C.E. (2017). Environmental Workplace Behaviors:Definition Matters. Organization \& Environment, 30(1), 51-70. http://dx.doi.org/10.1177/1086026615628036.

Cruz, C., Larraza-Kintana, M., Garcés-Galdeano, L., and Berrone, P. (2014). Are Family Firms Really More Socially Responsible? Entrepreneurship Theory and Practice, 38(6), 1295-1316. http://dx.doi.org/10.1111/etap.12125. 
Darnall, N., Henriques, I., and Sadorsky, P. (2008). Do environmental management systems improve business performance in an international setting? Journal of International Management, 14(4), 364-376. https://doi.org/10.1016/j.intman.2007.09.006.

Darnall, N., Henriques, I., and Sadorsky, P. (2010). Adopting Proactive Environmental Strategy: The Influence of Stakeholders and Firm Size. Journal of Management Studies, 47(6), 1072-1094. http://dx.doi.org/10.1111/j.1467-6486.2009.00873.x.

Das, A.K., Biswas, S.R., Jilani, M.M.A.K., and Uddin, M.A. (2019). Corporate Environmental Strategy and Voluntary Environmental Behavior - Mediating Effect of Psychological Green Climate. Sustainability, 11(11), 3123-3139. http://dx.doi.org/10.3390/su11113123.

Davis, H., and Macauley, P. (2011). Taking library leadership personally. The Australian Library Journal, 60(1), 41-53.

Dumont, J., Shen, J., and Deng, X. (2017). Effects of Green HRM Practices on Employee Workplace Green Behavior: The Role of Psychological Green Climate and Employee Green Values. Human Resource Management, 56(4), 613-627. http://dx.doi.org/10.1002/hrm.21792.

Edwards, M.R., and Kudret, S. (2017). Multi-foci CSR perceptions, procedural justice and in-role employee performance: the mediating role of commitment and pride. Human Resource Management Journal, 27(1), 169-188. http://dx.doi.org/10.1111/1748-8583.12140.

Eilam, E., and Trop, T. (2012). Environmental Attitudes and Environmental Behavior - Which Is the Horse and Which Is the Cart? Sustainability, 4(9), 2210-2246.

Eisenbeiß, S.A., and Boerner, S. (2013). A double-edged sword: Transformational leadership and individual creativity. British Journal of Management, 24(1), 54-68.

Fan, L., Mahmood, M., and Uddin, M.A. (2019). Supportive Chinese supervisor, innovative international students: a social exchange theory perspective. Asia Pacific Education Review, 20(1), 101-115. http://dx.doi.org/10.1007/s12564-018-9572-3.

Ferdausy, S., Rahman, M.S., Akter, R., Al-Amin, M., and Uddin, M.A. (2018). How do socially responsible human resource management and voluntary green behavior influence organizational competitiveness? Paper presented at the 1st International Conference on Finance for sustainable Growth and Development, Bangladesh.

Fu, L., Sun, Z., Zha, L., Liu, F., He, L., Sun, X., and Jing, X. (2020). Environmental awareness and pro-environmental behavior within China's road freight transportation industry: Moderating role of perceived policy effectiveness. Journal of Cleaner Production, 252, 119796. https://doi.org/10.1016/j.jclepro.2019.119796.

García-Quevedo, J., Kesidou, E., and Martínez-Ros, E. (2020). Driving sectoral sustainability via the diffusion of organizational eco-innovations. Business Strategy and the Environment, 29(3), 1437-1447. http://dx.doi.org/10.1002/bse.2443.

Gilal, F.G., Ashraf, Z., Gilal, N.G., Gilal, R.G., and Chaana, N.A. (2020). Promoting environmental performance through green human resource management practices in higher education institutions: A moderated mediation model. Corporate Social Responsibility and Environmental Management. http://dx.doi.org/10.1002/csr.1835.

Graves, L. M., Sarkis, J., and Zhu, Q. (2013). How transformational leadership and employee motivation combine to predict employee proenvironmental behaviors in China. Journal of Environmental Psychology, 35, 81-91. http://dx.doi.org/10.1016/j.jenvp.2013.05.002.

Hair Jr, J.F., Black, W.C., Babin, B.J., and Anderson, R.E. (2014). Multivariate Data Analysis: A Global Perspective (7 ed.). London: Pearson.

Hair Jr, J.F., Hult, G.T., Ringle, C.M., and Sarstedt, M. (2014). A primer on partial least squares structural equation modeling (PLS-SEM). SAGE Publications, Inc. 
Harangozó, G., Széchy, A., and Zilahy, G. (2015). Corporate Sustainability Footprints - A Review of Current Practices. In: S. Schaltegger, D. Zvezdov, I. Alvarez Etxeberria, M. Csutora, and E. Günther (eds.), Corporate Carbon and Climate Accounting (pp. 45-76). Cham: Springer International Publishing.

Homans, G.C. (1958). Social behavior as exchange. American Journal of Sociology, 63(6), 597-606.

Hooper, D., Coughlan, J., and Mullen, M. (2008). Structural equation modelling: Guidelines for determining model fit. Electronic Journal of Business Research Methods, 6(1), 53-60.

Jang, Y.J., Zheng, T., and Bosselman, R. (2017). Top managers' environmental values, leadership, and stakeholder engagement in promoting environmental sustainability in the restaurant industry. International Journal of Hospitality Management, 63, 101-111.

https://doi.org/10.1016/j.ijhm.2017.03.005.

Khan, M.A.S., Jianguo, D., Ali, M., Saleem, S., and Usman, M. (2019). Interrelations Between Ethical Leadership, Green Psychological Climate, and Organizational Environmental Citizenship Behavior: A Moderated Mediation Model. Frontiers in Psychology, 10(1977). http://dx.doi.org/10.3389/fpsyg.2019.01977.

Khan, S.A.R., Sharif, A., Golpîra, H., and Kumar, A. (2019). A green ideology in Asian emerging economies: From environmental policy and sustainable development. Sustainable Development, 27(6), 1063-1075. http://dx.doi.org/10.1002/sd.1958.

Khuwaja, U., Ahmed, K., Abid, G., Adeel, A. (2020). Leadership and employee attitudes: The mediating role of perception of organizational politics. Cogent Business \& Management, 7(1), 1720066.

Kil, N., Holland, S.M., and Stein, T.V. (2014). Structural relationships between environmental attitudes, recreation motivations, and environmentally responsible behaviors. Journal of Outdoor Recreation and Tourism, 7-8, 16-25. https://doi.org/10.1016/j.jort.2014.09.010.

Kim, A., Kim, Y., Han, K., Jackson, S.E., and Ployhart, R.E. (2017). Multilevel Influences on Voluntary Workplace Green Behavior: Individual Differences, Leader Behavior, and Coworker Advocacy. Journal of Management, 43(5), 1335-1358. http://dx.doi.org/10.1177/0149206314547386.

Kim, W. G., McGinley, S., Choi, H.-M., and Agmapisarn, C. (2019). Hotels' environmental leadership and employees' organizational citizenship behavior. International Journal of Hospitality Management, 102375. https://doi.org/10.1016/j.ijhm.2019.102375.

Koładkiewicz, I. (2009). Corporate social responsibility in Poland: the Responsible Business Forum 2002-2007 report perspective. Social Responsibility Journal, 5(1), 48-61. http://dx.doi.org/10.1108/17471110910939999.

Lechuga Sancho, M.P., Martínez-Martínez, D., Larran Jorge, M., and Herrera Madueño, J. (2018). Understanding the link between socially responsible human resource management and competitive performance in SMEs. Personnel Review, 47(6), 1211-1243. http://dx.doi.org/10.1108/pr-05-2017-0165.

Lee, J.W., Kim, Y.M., and Kim, Y.E. (2018). Antecedents of Adopting Corporate Environmental Responsibility and Green Practices. Journal of Business Ethics, 148(2), 397-409. http://dx.doi.org/10.1007/s10551-016-3024-y.

Liu, P., Teng, M., and Han, C. (2020). How does environmental knowledge translate into pro-environmental behaviors?: The mediating role of environmental attitudes and behavioral intentions. Science of the Total Environment, 138126. https://doi.org/10.1016/j.scitotenv.2020.138126.

Longoni, A., Luzzini, D., and Guerci, M. (2018). Deploying Environmental Management Across Functions: The Relationship Between Green Human Resource Management and Green Supply Chain Management. Journal of Business Ethics, 151(4), 1081-1095.

http://dx.doi.org/10.1007/s10551-016-3228-1. 
Mahmood, M., Uddin, M.A., and Luo, F. (2019). Influence of transformational leadership on employees' creative process engagement: A multi-level analysis. Management Decision, 57(3), 741-764. http://dx.doi.org/10.1108/MD-07-2017-0707.

Mahmood, M., Uddin, M.A., Ostrovskiy, A., and Orazalin, N. (2020). Effectiveness of business leadership in the Eurasian context: empirical evidence from Kazakhstan. Journal of Management Development, 39(9), 793-809. http://dx.doi.org/10.1108/JMD-05-2019-0154.

Michaelis, B., Stegmaier, R., and Sonntag, K. (2010). Shedding light on followers' innovation implementation behavior. Journal of Managerial Psychology, 25(4), 408-429. http://dx.doi.org/10.1108/02683941011035304.

Moore, C., Mayer, D.M., Chiang, F.F., Crossley, C., Karlesky, M.J., and Birtch, T.A. (2019). Leaders matter morally: The role of ethical leadership in shaping employee moral cognition and misconduct. Journal of Applied Psychology, 104(1), 123-145. http://dx.doi.org/10.1037/apl0000341.

Newman, A., Miao, Q., Hofman, P.S., and Zhu, C.J. (2016). The impact of socially responsible human resource management on employees' organizational citizenship behaviour: the mediating role of organizational identification. The International Journal of Human Resource Management, 27(4), 440-455. http://dx.doi.org/10.1080/09585192.2015.1042895.

Norton, T.A., Parker, S.L., Zacher, H., and Ashkanasy, N.M. (2015). Employee green behavior: A theoretical framework, multilevel review, and future research agenda. Organization \& Environment, 28(1), 103-125. http://dx.doi.org/10.1177/1086026615575773.

Paillé, P., Mejía-Morelos, J. H., Marché-Paillé, A., Chen, C.C., and Chen, Y. (2016). Corporate greening, exchange process among co-workers, and ethics of care: An empirical study on the determinants of pro-environmental behaviors at coworkers-level. Journal of Business Ethics, 136(3), 655-673.

Pham, H., and Kim, S.-Y. (2019). The effects of sustainable practices and managers' leadership competences on sustainability performance of construction firms. Sustainable Production and Consumption, 20, 1-14. https://doi.org/10.1016/j.spc.2019.05.003.

Podsakoff, P.M., MacKenzie, S.B., and Podsakoff, N.P. (2012). Sources of method bias in social science research and recommendations on how to control it. Annual Review of Psychology, 63, 539-569. https://doi.org/10.1146/annurev-psych-120710-100452.

Ramus, C.A. (2001). Organizational support for employees: Encouraging creative ideas for environmental sustainability. California Management Review, 43(3), 85-105.

Robertson, J.L., and Barling, J. (2013). Greening organizations through leaders' influence on employees' pro-environmental behaviors. Journal of Organizational Behavior, 34(2), 176-194. https://doi.org/10.1002/job.1820.

Robertson, J. L., and Carleton, E. (2018). Uncovering How and When Environmental Leadership Affects Employees' Voluntary Pro-Environmental Behavior. Journal of Leadership \& Organizational Studies, 25(2), 197-210. https://doi.org/10.1177/1548051817738940.

Safari, A., Salehzadeh, R., Panahi, R., and Abolghasemian, S. (2018). Multiple pathways linking environmental knowledge and awareness to employees' green behavior. Corporate Governance: The International Journal of Business in Society, 18(1), 81-103. https://doi.org/10.1108/CG-082016-0168.

Schneider, B., Ehrhart, M.G., and Macey, W.H. (2013). Organizational Climate and Culture. Annual Review of Psychology, 64(1), 361-388. https://doi.org/10.1146/annurev-psych-113011-143809.

Shen, J., and Benson, J. (2016). When CSR Is a Social Norm: How Socially Responsible Human Resource Management Affects Employee Work Behavior. Journal of Management, 42(6), 1723-1746. https://doi.org/10.1177/0149206314522300. 
Shen, J., Dumont, J., and Deng, X. (2018). Employees' perceptions of green HRM and non-green employee work outcomes: The social identity and stakeholder perspectives. Group \& Organization Management, 43(4), 594-622. https://doi.org/10.1177/1059601116664610.

Shen, J., and Zhang, H. (2019). Socially Responsible Human Resource Management and Employee Support for External CSR: Roles of Organizational CSR Climate and Perceived CSR Directed Toward Employees. Journal of Business Ethics, 156(3), 875-888. https://doi.org/10.1007/s10551-017-3544-0.

Shen, J., and Zhu, C.J. (2011). Effects of socially responsible human resource management on employee organizational commitment. The International Journal of Human Resource Management, 22(15), 3020-3035. https://doi.org/10.1080/09585192.2011.599951.

Souto, J.E. (2015). Business model innovation and business concept innovation as the context of incremental innovation and radical innovation. Tourism Management, 51, 142-155. https://doi.org/10.1016/j.tourman.2015.05.017

Srivastava, A.P., and Shree, S. (2019). Examining the effect of employee green involvement on perception of corporate social responsibility: Moderating role of green training. Management of Environmental Quality: An International Journal, 30(1), 197-210.

https://doi.org/10.1108/MEQ-03-2018-0057.

Sun, L., and Yu, T.R. (2015). The impact of corporate social responsibility on employee performance and cost. Review of Accounting and Finance, 14(3), 262-284. https://doi.org/10.1108/RAF-03-2014-0025.

Tian, Q., and Robertson, J.L. (2019). How and When Does Perceived CSR Affect Employees' Engagement in Voluntary Pro-environmental Behavior? Journal of Business Ethics, 155(2), 399-412. https://doi.org/10.1007/s10551-017-3497-3.

Tuan, L.T. (2019). Effects of environmentally-specific servant leadership on green performance via green climate and green crafting. Asia Pacific Journal of Management. https://doi.org/10.1007/s10490-019-09687-9.

Uddin, M.A., Akter, R., Al-Amin, M., Rahman, M.S., and Ferdausy, S. (2020). How Do Socially Responsible Human Resource Management and Voluntary Green Behavior Influence Organizational Competitiveness? Studies in Business and Economics, 15(2), 243-255. https://doi.org/ https://doi.org/10.2478/sbe-2020-0038.

Uddin, M.A., Alam, M.S., Mamun, A.A., Khan, T.-U.-Z., and Akter, A. (2020). A study of the adoption and implementation of enterprise resource planning (erp): Identification of moderators and mediator. Journal of Open Innovation: Technology, Market, and Complexity, 6(1), 2-19.

Uddin, M.A., Biswas, S.R., Bhattacharjee, S., Dey, M., and Mahmood, M. (2021). Inspiring employees' ecological behaviors: The roles of corporate environmental strategy, biospheric values, and eco-centric leadership. Business Strategy and the Environment, n/a(n/a). https://doi.org/10.1002/bse.2751.

Uddin, M.A., Mahmood, M., and Fan, L. (2019). Why individual employee engagement matters for team performance? Mediating effects of employee commitment and organizational citizenship behaviour. Team Performance Management: An International Journal, 25(1/2), 47-68. http://dx.doi.org/10.1108/TPM-12-2017-0078.

Uddin, M.A., Priyankara, H.P.R., and Mahmood, M. (2020). Does a creative identity encourage innovative behaviour? Evidence from knowledge-intensive IT service firms. European Journal of Innovation Management, 23(5), 877-894. https://doi.org/10.1108/EJIM-06-2019-0168.

Vokić, N.P. (2015). Competitiveness and sustainability of HRM activities in Croatia-CRANET survey results. EFZG working paper series, 15(6), 1-12. 
Yi, S., Li, X., and Jai, T.-M. (2018). Hotel guests' perception of best green practices: A content analysis of online reviews. Tourism and Hospitality Research, 18(2), 191-202. https://doi.org/10.1177/1467358416637251.

Yuriev, A., Boiral, O., Francoeur, V. and Paillé, P. (2018). Overcoming the barriers to pro-environmental behaviors in the workplace: A systematic review. Journal of Cleaner Production, 182, 379-394. https://doi.org/10.1016/j.jclepro.2018.02.041.

Yusliza, M.-Y., Norazmi, N. A., Jabbour, C.J.C., Fernando, Y., Fawehinmi, O., and Seles, B.M.R.P. (2019). Top management commitment, corporate social responsibility and green human resource management: A Malaysian study. Benchmarking: An International Journal.

Zikmund, W.G., Babin, B.J., Carr, J.C., and Griffin, M. (2010). Business Research Method (8th ed.). South-Western, Canada: Cengage Learning. 